\title{
WORKPLACE ENVIRONMENT IN LATVIA
}

Mareks Niklass ${ }^{1}$, Dr.sc.soc./ researcher ${ }^{1}$ University of Latvia

\begin{abstract}
The aim of the article is to find out how the workplace environment in Latvia has changed over the last 20 years and what factors account for the overall job satisfaction. The author analyses the available labour statistics and data from three ISSP Work Orientation studies carried out in 1997, 2005 and 2016 in Latvia. The questionnaire items related to one's evaluation of job security, income, opportunities for advancement and overall job satisfaction are the focus of the article. More and more respondents agree with the statements such as "my job is secure", "my income is high", and "my opportunities for advancement are high". The labour statistics and multiple linear regression analysis support the hypothesis that higher incomes and more opportunities for advancement would increase the overall job satisfaction. Although younger cohorts and those with higher education have higher employment rates and more prospects for career advancement, the analysis shows that these groups are not more satisfied with their jobs than employees in other groups. Other factors such as interesting work, stress, relationships with management and pride in one's job are better predictors of the overall job satisfaction.
\end{abstract}

Key words: job security, job satisfaction, Latvia, ISSP.

JEL code: 328

\section{Introduction}

Workplace environment encompasses not only a physical space but also a social milieu where work takes place. The focus of this article is a social context of work and its relationship with one aspect of job quality, i.e. job satisfaction. OECD experts have identified a number of dimensions to be considered when measuring employment quality - earnings, working hours and time, job security, life-long learning, safety and health at work (stress at work), work organisation and content (autonomy), workplace relationships (relationships with colleagues and supervisors) and social security systems (OECD, 2013, p. 150). Some of those dimensions are also analysed below. Large scale surveys (ISSP, British Household Panel Survey) have identified correlations between job satisfaction and job outcomes such as relations at work, job content, promotion opportunities, incomes and job security (Clark, 2015, p. 7). In other words, having a paid job is no longer sufficient to draw satisfaction from one's job. A meaningful job and good relationships with colleagues matter, too.

The author analyses the available labour statistics and data from three ISSP Work Orientation studies carried out in 1997, 2005 and 2016 in Latvia. The questionnaire items related to one's evaluation of job security, income, opportunities for advancement and overall job satisfaction are the focus of the article. There have been a plenty of labour market studies focusing on a wide array of aspects (migration, mobility, discrimination, gender, age) in Latvia. The most notable example is a research programme "Labour Market Studies" organized by the Ministry of Welfare in 2006-2007 (Labklajibas ministrija, s.a.). However, these studies did not focus on the longitudinal aspect of labour market development. This article seeks to remedy the situation and attempts to analyse long term changes in attitudes regarding one's job. A long term perspective allows discerning some trends that are hardly visible in ad hoc measurements. Public discourse is quite critical to the development in Latvia economy and labour market. Positive changes, as this article suggests, are rarely identified, mentioned or acknowledged. First, the article provides background information on the development of Latvia economy and labour market since 1996. Second, the author analyses the survey data from three ISSP studies on work orientations fielded in 1997, 2005 and 2016. Third, the article reflects on how economic and labour market changes have shaped the attitudes of 
the employed towards their job. The main goal is to find out what factors account for the overall job satisfaction. The author proposes the following theses that may account for the overall job satisfaction. High incomes and more prospects for career advancement would increase the job satisfaction level. Younger cohorts and those with higher education would be more satisfied with their jobs than employees in other groups.

\section{Research results and discussion}

\section{Changes in Latvian economy and labour market since 1996}

Since 1996, Latvia experienced a steady economic growth with a significant setback during the economic crisis from 2008 to 2010. In 1996, GDP per capita was 1904 EUR (in the current prices). In 2016, the figure reached 12762 EUR (Central Statistical Bureau of Latvia, 2017e). A number of factors might account for such a growth. First, it is easier to achieve the growth rate from a low base. Latvian goods could be exported cheaply because of low production costs. Second, the prospects of Latvia becoming an EU Member State drew a lot of private investments from abroad. As an OECD report on the financial system in Latvia in 2016 indicates, the share of foreign ownership of banks in Latvia was $85.8 \%$ (OECD, 2016, p. 15). Those investments caused a boom in the real estate sector and a staggering increase in prices and wages. Third, the membership in the EU gives Latvia an opportunity to access EU funding and cheap credit. It also allowed to weather through the economic crisis more easily.

The economic growth brought changes in the structure of Latvia economy, too. In 2000 (when the latest comparable data are available), the share of real estate sector constituted $6.5 \%$ of the total gross value added. In 2016, the figure was $13 \%$. Similarly, though to a lesser extent, the share of financial and insurance sector grew from $3.3 \%$ to $5.7 \%$ in the same period (Central Statistical Bureau of Latvia, 2017f). Two big sectors where there were a large number of jobs in the past, namely manufacturing and agriculture, lost their share in the economy of Latvia. In the manufacturing sector, from $19.6 \%$ in 2000 to $16.7 \%$ in 2016. In the agricultural sector, from $5.1 \%$ to $3.2 \%$ (Central Statistical Bureau of Latvia, 2017f). There are now more jobs for professionals with university diploma and fewer jobs for low skilled and blue collar workers.

The economic growth created job opportunities for all but especially for young professionals. The employment rate in the age group 15-64 grew from $57 \%$ in 1996 to $68 \%$ in 2016 (Central Statistical Bureau of Latvia, 2017a). In the age group 25-34, the employment rate rose from $68.8 \%$ to $79.7 \%$. However, persons in their preretirement age face significant problems in getting a job and retaining it. In 1996, only $33.1 \%$ were employed in the age group. In 2016, the employment rate for the group was $61.4 \%$ (Central Statistical Bureau of Latvia, 2017a). A few factors account for the lower employment rates for older people. A report by the World Bank on active aging in Latvia indicates (2015) that: "Outdated skills, health problems, alternative income sources, care responsibilities, and place of residence all affect labour supply among the elderly" (p.8). Furthermore, the prevailing stereotypes and discrimination on the part of some members of society may have effect on the employment levels of the older workers as well (Karnite, R., 2.06.2013.).

The possession of certain skills is rewarded in the labour market of Latvia. The absolute number and share of persons with university diploma has increased from 1996 to 2016. In 1996, there were $19.6 \%$ with higher education among the employed. In 2016, the share reached $37.1 \%$. The similar figures for the persons with basic education were $11.6 \%$ and $7.4 \%$, for those with 
vocational education $45.6 \%$ and $32.6 \%$ respectively (Central Statistical Bureau of Latvia, 2017a). The share of the less educated decreased because of restructuring in the manufacturing and agricultural sectors. Another reason could be the diminishing prestige of vocational education in Latvian society (Zalaiskalne, A., 2013). Vocational education is often not considered as a reasonable option for further education among young people.

Despite the economic growth and the rise of highly rewarding industries, Latvia had a considerable depopulation due to low birth rate and mass emigration. In the beginning of 1996, there were 2.469.531 persons residing in Latvia. In 2016, only 1.968 .957 (Central Statistical Bureau of Latvia, 2017c). Since 1996, there has never been a population increase. The population decrease rate varied from 1 to $2 \%$ annually (Central Statistical Bureau of Latvia, 2017c).

Mass emigration was spurred by a number of factors. Latvia's accession to the EU opened the labour market in Western Europe. Many sought a job in Great Britain, Ireland, Germany and Norway (McCollum, D. et. al., 2016, p. 4). The economic recession from 2008 to 2010 increased the number of those settling abroad. Hazans (2016) argues that higher income and better working conditions abroad are the most important pull factors and one's joblessness, wage cuts and inability to pay back credits are the most often indicated push factors among emigrants (p.311).

The economic growth brought also seemingly high wage increases. However, wages are still low in comparison with Western European countries. In 1996, the average gross monthly wage was 140 EUR. In 2016, it was 856 EUR (Central Statistical Bureau of Latvia, 2017g). It should be noted that mass emigration had a positive side effect. Lehmann, Razzolini and Zaiceva argue that mass emigration mitigated the effect of the crisis on wage and unemployment levels in Latvia (Lehmann, H., Razzolini, T. \& Zaiceva A., 2017). Most likely, wage cuts and unemployment might have been more severe if many emigrants would have stayed in Latvia.

Despite the economic growth and negative net migration, the unemployment rate remained very high throughout the time period from 1996 to 2016. In the beginning of the period, the rate stood at $20.5 \%$. Then it dropped to $6.2 \%$ in 2007 when there was the economic boom. In 2009 in the bottom of the economic crisis, the unemployment rate reached $19.8 \%$. Since the beginning of the recovery in 2011, the rate dropped to $9.9 \%$ in 2016 (Central Statistical Bureau of Latvia, 2017c).

Stark regional differences are an established phenomenon in Latvia. Riga, the capital city, is the hub of economic and labour market activities with the lowest unemployment rate, the highest incomes and the best career prospects. In comparison, Latgale had one of the highest unemployment rates in Latvia, the lowest GDP per capita. In 2016, the unemployment rate in Latgale was $13.1 \%$. In Riga, $6.1 \%$ (Central Statistical Bureau of Latvia, 2017h). In 2014, GDP per capita in Latgale was 5,981 EUR. The figure for Riga - 19912 EUR (Central Statistical Bureau of Latvia, 2017d).

To sum up, Latvia economy and labour market have experienced extraordinary changes and volatility since 1996. GDP per capita increased almost six fold. Wages increased in the similar manner. The share of the manufacturing and agricultural sectors decreased substantially with the loss of many low skilled and semi - skilled jobs. There are now more jobs for professionals with university diplomas in the financial and real estate sectors. Employment levels in all age groups increased, unemployment fell for the most of the period, except the economic recession during 2008 to 2011. Regional differences remain a permanent feature in Latvia even after twenty years. Riga, the capital city, is doing much better than other regions, especially Latgale, which faces 
economic stagnation and mass unemployment. Latvia lost many economically active people due to depopulation and mass emigration. The demographic process may have a negative impact in the long run but it also mitigated the effects of the economic crisis by decreasing unemployment and sustaining wage levels. In short, an average person in Latvia in 2016 was considerably better off, had more employment opportunities and experienced less competition than in 1996.

\section{Data and methodology}

Survey data analysed in this article were gathered in 1997, 2005 and 2016 in the framework of the International Social Survey Programme (ISSP). Samples were representative to the 18-74year-old population in Latvia. The author analysed only those questionnaire items that were included in all three surveys. The questionnaires in ISSP studies have a core of items and a set of questions that were included once or twice. The author did not include the latter items. He also looked at the items that were relevant only to the working population. All data presented in the following tables are weighted to adjust for the under-coverage of some social groups (young males, persons from ethnic minority backgrounds).

\section{Empirical results}

A battery of statements about one's job was included in the questionnaire such as "'My job is secure", "My income is high" etc. The five point Likert scale was used to identify a level of agreement with the above statements where 1 represents a response category "strongly agree" and 5 - "strongly disagree". For the items "How often do you have to do hard physical work" and "How often do you find work stressful", the five point Likert scale was used with response categories 1 - always and 5 - never. For the items "Relations between management and employees" and "Relations between workmates/ colleagues", 1 represents "very good" and 5 "very bad". For the item "How satisfied are you in your (main) job", the seven point scale was used to measure the overall job satisfaction, where 1 denotes "completely satisfied" and 7 - "completely dissatisfied". Smaller values identify more agreement and satisfaction. Negative differences in means should be interpreted as positive changes, i.e. better relationships with colleagues and more interesting jobs. Table 1 provides the descriptive statistics of those responses.

The overall satisfaction with the main job has increased since 1997. The trend is discernible through the three ISSP studies when this measurement was taken. It holds true for other measurements, too. More and more people agree with the statements "My job is secure", "My income is high" and "My opportunities for advancement are high".

It seems that respondents are now less willing to work harder for a firm to succeed than in 1997. In other words, their work commitment is less pronounced. Although people feel more secure at their job, it does not affect their perception of work stress. There are no changes in how often people find their work stressful. Surprisingly and on the contrary to what one might expect in the era of ICT, many respondents admit that they often do hard physical work. At last, it appears that relationships between management and colleagues (and among themselves) have become slightly better. Respondents more frequently point out that their work relationships are very good or quite good.

To sum up, the workplace environment in Latvia is becoming more friendly and secure. There are more opportunities for career advancement than before. More and more people admit that they have high incomes, too. As a result, there are more satisfied employees in 2016 than in 1997. 
To find out which factors account for the overall job satisfaction and how they have changed over time, the author carried out multiple linear regression analysis. Beta coefficients and p-values are included in Table 2.

Table 1

Self-evaluation of one's job

\begin{tabular}{|c|c|c|c|c|c|c|c|c|}
\hline & \multicolumn{2}{|c|}{1997} & \multicolumn{2}{|c|}{2005} & \multicolumn{2}{|c|}{2016} & \multirow{2}{*}{$\begin{array}{c}\text { Difference } \\
\text { in means } \\
2016-1997\end{array}$} & \multirow{2}{*}{$\%$ change } \\
\hline & $\mathbf{M}$ & SD & $\mathbf{M}$ & SD & $\mathbf{M}$ & SD & & \\
\hline My job is secure & 2.98 & 1.35 & 2.71 & 1.14 & 2.21 & 1.10 & -0.77 & -25.86 \\
\hline My income is high & 4.02 & 0.99 & 3.68 & 0.98 & 3.32 & 1.03 & -0.71 & -17.61 \\
\hline $\begin{array}{l}\text { My opportunities for } \\
\text { advancement are high }\end{array}$ & 3.96 & 1.16 & 3.62 & 1.02 & 3.43 & 1.15 & -0.53 & -13.43 \\
\hline My job is interesting & 2.32 & 1.20 & 2.56 & 1.04 & 2.16 & 1.05 & -0.17 & -7.18 \\
\hline I can work independently & 2.62 & 1.36 & 2.89 & 1.15 & 2.76 & 1.29 & 0.14 & 5.19 \\
\hline $\begin{array}{l}\text { In my job I can help other } \\
\text { people }\end{array}$ & 2.16 & 1.12 & 2.31 & 0.91 & 2.06 & 0.99 & -0.10 & -4.83 \\
\hline My job is useful to society & 1.77 & 0.83 & 2.13 & 0.81 & 1.87 & 0.85 & 0.10 & 5.93 \\
\hline $\begin{array}{l}\text { How often do you have to } \\
\text { do hard physical work }\end{array}$ & 3.50 & 1.39 & 3.29 & 1.40 & 3.06 & 1.46 & -0.45 & -12.71 \\
\hline $\begin{array}{l}\text { How often do you find work } \\
\text { stressful }\end{array}$ & 3.01 & 1.15 & 2.93 & 1.06 & 2.99 & 1.25 & -0.02 & -0.82 \\
\hline $\begin{array}{l}\text { Relations between } \\
\text { management and employees }\end{array}$ & 2.15 & 0.73 & 2.29 & 0.89 & 1.93 & 0.77 & -0.22 & -10.44 \\
\hline $\begin{array}{l}\text { Relations between } \\
\text { workmates/ colleagues }\end{array}$ & 1.90 & 0.59 & 1.93 & 0.74 & 1.72 & 0.64 & -0.18 & -9.64 \\
\hline $\begin{array}{l}\text { I am willing to work harder } \\
\text { than I have to in order to help } \\
\text { the firm or organization I work } \\
\text { for succeed }\end{array}$ & 2.56 & 1.19 & 3.06 & 1.09 & 2.89 & 1.21 & 0.33 & 13.08 \\
\hline $\begin{array}{l}\text { I am proud to be working for } \\
\text { my firm or organization }\end{array}$ & 2.51 & 1.10 & 2.89 & 1.02 & 2.36 & 1.02 & -0.15 & -5.85 \\
\hline $\begin{array}{l}\text { How satisfied are you in your } \\
\text { (main) job }\end{array}$ & 2.90 & 1.16 & 3.11 & 1.16 & 2.63 & 1.22 & -0.27 & -9.38 \\
\hline
\end{tabular}

*M - mean, SD - standard deviation

** Base - the working population 
Beta coefficients of variables included in multiple linear regression analysis

\begin{tabular}{|c|c|c|c|c|c|c|}
\hline & \multicolumn{2}{|c|}{ 1997* } & \multicolumn{2}{|c|}{ 2005** } & \multicolumn{2}{|c|}{$2016 * * *$} \\
\hline & b & $\begin{array}{l}\text { p-va } \\
\text { lue }\end{array}$ & b & $\begin{array}{l}\text { p-va } \\
\text { lue }\end{array}$ & b & $\begin{array}{l}\text { p-va } \\
\text { lue }\end{array}$ \\
\hline Constant & 1.195 & .005 & .777 & .007 & .568 & .040 \\
\hline Age & -.011 & .004 & $\begin{array}{c}- \\
.011\end{array}$ & .001 & -.017 & .000 \\
\hline Sex (males) & .099 & .328 & $\begin{array}{c}- \\
.215\end{array}$ & .004 & .147 & .076 \\
\hline Region (Riga) & .146 & .147 & .119 & .098 & .038 & .641 \\
\hline $\begin{array}{l}\text { Education (higher } \\
\text { education) }\end{array}$ & .048 & .695 & .286 & .001 & .116 & .202 \\
\hline My job is secure & .082 & .045 & .087 & .017 & .034 & .372 \\
\hline My income is high & .109 & .049 & .085 & .049 & .215 & .000 \\
\hline $\begin{array}{l}\text { My opportunities for } \\
\text { advancement are high }\end{array}$ & -.004 & .929 & .098 & .023 & .075 & .064 \\
\hline My job is interesting & .343 & .000 & .223 & .000 & .277 & .000 \\
\hline I can work independently & .006 & .862 & .037 & .299 & .086 & .008 \\
\hline $\begin{array}{l}\text { In my job I can help other } \\
\text { people }\end{array}$ & .058 & .289 & .014 & .788 & .024 & .599 \\
\hline My job is useful to society & .099 & .195 & .091 & .112 & -.035 & .518 \\
\hline $\begin{array}{l}\text { How often do you have to } \\
\text { do hard physical work }\end{array}$ & .016 & .686 & $-\overline{0} \cdot$ & .001 & -.059 & .042 \\
\hline $\begin{array}{l}\text { How often do you find } \\
\text { work stressful }\end{array}$ & -.213 & .000 &. & .006 & -.119 & .000 \\
\hline $\begin{array}{l}\text { Relations between } \\
\text { management and } \\
\text { employees }\end{array}$ & .247 & .002 & .171 & .001 & .223 & .001 \\
\hline $\begin{array}{l}\text { Relations between } \\
\text { workmates/ colleagues }\end{array}$ & -.155 & .106 & .198 & .000 & .169 & .023 \\
\hline $\begin{array}{l}\text { I am willing to work harder } \\
\text { than I have to in order to } \\
\text { help the firm or } \\
\text { organization I work for } \\
\text { succeed }\end{array}$ & .030 & .538 & .090 & .043 & .012 & .748 \\
\hline $\begin{array}{l}\text { I am proud to be working } \\
\text { for my firm or organization }\end{array}$ & .204 & .000 & .156 & .002 & .251 & .000 \\
\hline
\end{tabular}

*For the study in $1997, n=366, F(17,348)=16.679, p=.000, R 2=.449$

**For the study in 2005, $n=552, F(17,534)=33.795, p=.000, R 2=.518$

$* * *$ For the study in 2016, $n=548, F(17,530)=31.686, p=.000, R 2=.504$

$* * * *$ Cases with Cook's distance values $>=1$ (influential cases) and standardized residual values $>=3$ (outliers) were not included

It appears that there are a few significant and stable factors in determining one's job satisfaction over the span of nearly 20 years. One's age is a good predictor of one's job satisfaction. Older employees are more satisfied with their jobs than the young. It is contrary to a widely shared belief that young people with higher education have more career prospects and better paid jobs. Somewhat surprisingly, region (place of residence in Riga) is not a statistically significant predictor although official statistics suggest that there are more job opportunities and a higher living standard in the capital city. Education is not a significant factor as one might expect. It can be argued that the current labour market creates more jobs and career prospects for professionals, i.e. people with higher education. However, it does not translate into the higher satisfaction levels of the highly educated employees. The agreement with the statements like "My income is high", "My job is interesting" and "I am proud to be working for my firm or organization" will most likely result in higher satisfaction levels. Similarly, good relationships with management 
and colleagues do have a positive effect on one's job evaluation. However, stress and physical work have a negative impact on one's job satisfaction. Those who experienced that more often are less satisfied with their jobs. Job security was a significant factor in 1997 and 2005 but not in 2016. Work independence now seems to have more impact on one's job satisfaction. Only the next round of the ISSP study will show whether this is an established trend.

To sum up the results of the regression analysis, sociodemographic indicators (like sex, region, and education with the exception of age) have no statistically significant effect on the overall job satisfaction. There are more important factors that account for the satisfaction, i.e. interesting work, one's income, relationships with management and a pride in one's job. It matters more not who one is but what kind of job one has.

\section{Discussion}

Labour statistics clearly show that wages and employment rates significantly increased since 1996. In other words, there are proportionally more better paid jobs than before. The analysed survey results do reflect these trends. Respondents more often acknowledge that they have high incomes and opportunities for advancement. There are less unemployment and less pressure on the employed to be concerned about job loss. As a result, employees now feel more secure about their jobs than previously. Although to a lesser degree than one might expect from the presented results, the overall job satisfaction has also increased.

Although the labour market structure significantly changed over time (with more jobs for professionals with higher education in sectors such as real estate and financial services), the selfevaluation of one's job content and value did not changed that much (within or close to the margin of sampling error). Interesting and useful work, a pride in one's job, the opportunities for working independently and helping other people are no more or no less common in 2016 than in 1997.

To a certain degree, multiple linear regression analysis supports the hypothesis that higher incomes would increase the overall job satisfaction. However, the analysis does not support that opportunities for career advancement is a contributing factor. Although there are now more jobs for individuals with higher education (as labour statistics suggest) and more respondents acknowledge that their opportunities for advancement are high, it does not have an effect on their evaluation of job satisfaction.

Factors such as sex, region and education have no effect on the overall job satisfaction. The regression analysis does not support the hypothesis that those with higher education may have higher job satisfaction levels. The questionnaire used in the ISSP studies does not include items on the content (tasks, responsibilities) of one's job that might explain why it is so. The author might speculate that jobs offered to university graduates often do not meet their expectations. A university graduate is probably more aware of different career options and the situation in the labour market. He may be more critical in evaluating his job as well.

The regression analysis also does not support the hypothesis that younger cohorts might be more satisfied with their job because they have more opportunities for advancement. Labour statistics shows that employment rates for younger cohorts are higher; therefore, it would be reasonable assume that there are more job prospects for those cohorts. The older cohorts, however, have lower employment rates and, as a few reports suggest (World Bank, 2015; Karnite, R., 2.06.2013.), may have outdated skills and often face discrimination in the labour market. If it is so, one might expect that older people would feel less satisfied with their job but it is otherwise. 
Again, the author speculates that older cohorts have lower expectation levels but the thesis should be tested in empirical research in the future.

At last, the analysis indicates the importance of non-material factors such as interesting job, good relationships with management, stress and taking pride in one's job. They are often overlooked in public discourse on employment relations and policy options. The future research in Latvia should focus more on what constitutes interesting work and how to foster good relationships with management. Higher salaries and new job prospects will not be enough to motivate and to keep employees engaged in the $21^{\text {st }}$ century.

\section{Conclusions}

1) There has been a significant increase in wages and employment rates in all age groups since 1996 in Latvia. There is now less unemployment and less pressure on the employed, too. Some differences between groups though remain. Younger cohorts have higher employment rates and those living in Riga enjoy higher wages.

2) The labour market structure has radically changed during the last 20 years. There are now more jobs for professionals with higher education in sectors such real estate and financial services.

3) Throughout the period between 1997 and 2016 when the ISSP studies on work orientation were carried out, respondents more and more often acknowledged that they had high incomes, more prospects for advancement and they felt more secure. As a result, there are now more employees who are satisfied with their jobs.

4) Multiple linear regression analysis supports the thesis that higher wages would result in higher job satisfaction levels. However, better career prospects, as labour statistics and empirical evidence suggested, would not lead to higher satisfaction.

5) The regression analysis does not support the theses that younger employees and those with higher education may have higher job satisfaction levels. The author speculates that the aforementioned groups have different expectations than those with less education and in older cohorts, but these assumptions should be tested in empirical research in the future.

6) There are a few factors that account for the overall job satisfaction - age, income, interesting work, stress, relationships with management and pride in one's job. High incomes, engaging jobs, good relationships with management, less stress at workplace and taking pride in one's job would identify high satisfaction levels. It matters more not who one is but what kind of job one has.

\section{Acknowledgements}

This research is supported by National Research Programme "Innovation and Sustainable Development: Latvia's Post-Crisis Experience in a Global Context" (SUSTINNO)

\section{Bibliography}

1. Central Statistical Bureau of Latvia. (2017a). Activity Rate, Employment Rate and Unemployment rate ( \%). Retrieved:

http://data.csb.gov.Iv/pxweb/en/Sociala/Sociala__ikgad__nodarb/?tablelist=true\&rxid=86924cfc-43254894-a3d5-ca9e0c89b394. Access 19.12.2017.

2. Central Statistical Bureau of Latvia. (2017b). Average Monthly Wages and Salaries (in Euro; as per Cent of Previous Year). Retrieved: http://www.csb.gov.Iv/en/statistikas-temas/metodologija/average-and-realmonthly-wages-and-salaries-36647.html. Access 19.12.2017.

3. Central Statistical Bureau of Latvia. (2017c). Changes of Resident Population by Factor. Retrieved: http://data.csb.gov.Iv/pxweb/en/Sociala/Sociala_ikgad_iedz_iedzskaits/IS0030.px/?rxid=562c2205ba57-4130-b63a-6991f49ab6fe. Access 19.12.2017. 
4. Central Statistical Bureau of Latvia. (2017d). Gross Domestic Product by Statistical Region and City (at Current Prices). Retrieved:

http://data.csb.gov.Iv/pxweb/en/ekfin/ekfin_ikgad_ikp/IK10_0110.px/table/tableViewLayout2/?rxid=cdcb 978c-22b0-416a-aacc-aa650d3e2ce0. Access 19.12.2017.

5. Central Statistical Bureau of Latvia. (2017e). Gross Domestic Product, per Capita, Euro. Retrieved: http://data.csb.gov.Iv/pxweb/en/ekfin/ekfin_isterm_ikp/?tablelist=true\&rxid=86924cfc-4325-4894-a3d5ca9e0c89b394. Access 19.12.2017.

6. Central Statistical Bureau of Latvia. (2017f). Total Gross Value Added by Kind of Activity (Nace Rev.2) (at Current Prices). Retrieved:

http://data.csb.gov.Iv/pxweb/en/ekfin/ekfin_ikgad_ikp/?tablelist=true\&rxid=73841663-21d9-441b-92919 ef07dc155fd. Access 19.12.2017.

7. Central Statistical Bureau of Latvia. (2017g). Trends in Real Wages and Salaries of Employees (As Per Cent Of Previous Year). Retrieved:

http://data.csb.gov.Iv/pxweb/en/Sociala/Sociala_ikgad_dsamaksa/?tablelist=true\&rxid=cd

8. Central Statistical Bureau of Latvia. (2017h). Unemployment Rate by Statistical Region (\%). Retrieved: http://data.csb.gov.Iv/pxweb/en/Sociala/Sociala_ikgad_nodarb/NB0040.px/?rxid=562c2205-ba57-4130b63a-6991f49ab6fe. Access 19.12.2017.

9. Clark, A. (2015). What Makes a Good Job? Job Quality and Job Satisfaction. IZA World of Labor 2015: 215, doi: $10.15185 /$ izawol. 215

10. Hazans, M. (2016). Migration Experience of the Baltic Countries in the Context of Economic Crisis. In M. Kahanec \& K. F. Zimmermann (Red.), Labor Migration, EU Enlargement, and the Great Recession Berlin. Heidelberg: Springer Berlin Heidelberg. pp.297-344. Retrieved: http://dx.doi.org/10.1007/978-3-66245320-9_13

11. Karnite, R. (2.06.2013). Latvia: the Role of Governments and Social Partners in Keeping Older Workers in the Labour Market. European Observatory of Working Life. Retrieved: https://www.eurofound.europa.eu/observatories/eurwork/comparative-information/nationalcontributions/latvia/latvia-the-role-of-governments-and-social-partners-in-keeping-older-workers-in-thelabour-market. Access 19.12.2017.

12. Labklajibas ministrija. (b.g.). Labklajibas ministrijas petijumi (13 nacionalas programmas petijumi). Retrieved: http://www.Im.gov.Iv/text/674. Access 19.12.2017.

13. Lehmann, H., Razzolini, T. \& Zaiceva A. (2017). Internal Devaluation and Labor Market Outcomes: Evidence from Latvia. Working Paper DSE N¹095. Retrieved: http://amsacta.unibo.it/5513/1/WP1095.pdf. Access 19.12.2017.

14. McCollum, D., Apsite-Berina, E., Berzins, M., \& Krisjane, Z. (2016). Overcoming the Crisis: the Changing Profile and Trajectories of Latvian Migrants. Journal of Ethnic and Migration Studies, 1-18. https://doi.org/10.1080/1369183X.2016.1232161

15. OECD. (2013). Well Being in the Workplace: Measuring Job Quality, in How's Life? 2013: Measuring Wellbeing, OECD Publishing, Paris. http://dx.doi.org/10.1787/how_life-2013-9-en

16. OECD. (2016). Latvia: Review of the Financial System. Retrieved: https://www.oecd.org/finance/Latviafinancial-markets-2016.pdf. Access 19.12.2017.

17. World Bank. (2015). The Active Aging Challenge for Longer Working Lives in Latvia. Overview Report: Main Messages and Policy Recommendations. Retrieved: http://www.Im.gov.Iv/upload/aktualitates2/wb_Iv_active_aging_exec_summary_011015.pdf. Access 19.12.2017.

18. Zalaiskalne, A. (2013). Contemporary learning environment in the vocational education: the new challenges. The problems of education in the $21^{\text {st }}$ century. Volume 55. Retrieved: http://oaji.net/articles/2014/457-1420055220.pdf. Access 19.12.2017. 